\title{
OF IMMORAL EXTINCTION AND THE COLLAPSE OF THE WORLD: SCHELLING AND THE COMMITMENTS OF FREEDOM
}

\author{
Virgilio A. Rivas \\ Polytechnic University of the Philippines/ \\ University of Santo Tomas Manila
}

\begin{abstract}
In his earlier work on the System of Transcendental Idealism (1800), which combined Naturphilosophie and transcendental philosophy, Schelling argued that it is only by becoming-art that philosophy can complete itself as a discipline. He proposed this formulation in response to Kant's critical inventory of reason offering to reclaim philosophy from its entanglement in pre-critical or dogmatic traditions. But Kant avoided to ground reason in the notion of externality, the in-itself, which, owing to its pre-critical derivation, must give way to the a prioris and categories of the understanding. Meanwhile, by renewing the problem of the in-itself via the self-positing ego, Fichte was the first to challenge the Kantian legacy. But the emphasis on subjectivity through its power of self-positing gave way to what in principle negates nature as the true ground of the initself; in Schelling's description, the equivalent of the annihilation of nature. Comparatively, Schelling proposed to demonstrate the reverse, which is the extinction of the subject that has continued to nourish the reflexive standpoint of reason. To accomplish this end, Schelling invoked in his Philosophy of Art, one of the places in which he extended his discussion of the so-called identity-system, the concept of the ideal type, or rather, the destroyer of known world established by critical reason.
\end{abstract}

\section{INTRODUCTION}

In his Würzburg Lectures of 1804-05, F.W.J. Schelling (1989, 35) expands his conception of identity-system in terms of navigating the discipline of the arts, thereby incorporating his previous insights in regard to the concept of the 'absolutely identical' earlier worked out in the System of Transcendental Idealism of 1800 (2001). In the 1800 System, Schelling $(1989,17)$ introduced the crucial role of the arts in lending objectivity to concepts which, comparatively speaking, due to its speculative remit, philosophy may not be up for the task. Philosophy, however, remains the only science 
of knowledge that is capable of comprehending the absolute. To shed light on the relation between philosophy and art, Schelling $(1989,17)$ proceeds to answer, among others, the question of how the absolute (also described as the enduring archetype of truth) can unfold into distinctive levels of "multiplicity and differentiations," or the question, "how individual beautiful things can issue from universal or absolute beauty," as the following lines suggest:

Philosophy answers this question with the doctrine of the ideas or archetypes. The absolute is absolutely one; viewed absolutely in particular forms, however, such that the absolute is thereby not suspended, this one $=$ idea. The same holds true for art. It, too, views or intuits primal beauty only in ideas of particular forms... Whereas philosophy intuits these ideas as they are in themselves, art intuits them objectively.

The task of attaining the philosophical objectivity of the absolute falls on aesthetics. The arts not only provide philosophy with a model of objectivity, but also secure its possibility of attaining self-awareness (i.e., self-intuition). In terms of how the subjectivity of the artist manifests in her finite creations as objectively as possible, philosophy needs the model of the arts whereby the subjective is transmitted into the realm of the objective (Schelling 1989, 8). Art serves as a critical reference for philosophy as to how objectivity can thus be attained. This means that with art subjective materials can be taken up into a whole system of ideas.

This interdependence refers to the co-implication of art and philosophy via their common object (Nature). Nature is the focal point of this fundamental relation as it articulates a purpose for both disciplines; a purpose, nevertheless, "which does not appear on its own in such a way that it is purposively ordered for itself" (Dodd 1998, 79). Both can only see this purpose in Nature via the idea of free construction that "begins as unconscious and ends as conscious, the process of production is not purposive but the product certainly is so" (Schelling 2001, 219). In the following, Schelling explains the notion of free construction, apropos of the duality of nature (as product and production) that is freely intuited by the self: "The self must begin (subjectively) with consciousness, and end without consciousness, or objectively; the self is conscious in respect of production, unconscious in regard to the product" (2001, 219).

In both processes, the subjective and objective return in the originating process of nature that can be freely intuited as having a purpose of its own, no longer operating as blind mechanism. In the genuine sense of purposiveness, as Schelling $(2001,216)$ argues, "intention and purpose are absent," independent of the motive of the present, in contrast to the, "teleological modes of expression," by means of which, at the beginning "intension is insisted upon." Intention is an outcome of free construction, not in itself the inherent tendency of blind mechanism; in a word, "not purposive in its origin" (Schelling 2001, 215). Thus, in the matter of free construction, Schelling advanced the identity-system between art and philosophy culminating in the unity of 
the two grounding sciences that the 1800 System worked out in detail, i.e., the philosophy of nature and transcendental philosophy (which represents the science of reason). Here the philosophy of nature represents the real via aesthetic intuition that treats ordinary experiences in their original and natural contexts (Schelling 2001, 23132 ), and transcendental philosophy via the a prioris of critical reason which represent, as it were, the ideal. James Dodd $(1988,54)$ provides a helpful annotation of this identity-system as follows:

Here the topic is construction, in particular the relationship between the ideal and the real, form and content within construction. Any absolute division of the ideal and the real is being denied, while an absolute identity is being affirmed as the identity of the Absolute.... Identity here is an identity in difference, as its preferred way of being itself were to be other than itself.

Be that as it may, for the unity of these two sciences to be possible, Naturphilosophie must forge a cooperative model or a critical link to transcendental philosophy. In turn, transcendental philosophy must establish a reciprocal link to the philosophy of nature whose connection to the ideal should give way to the highest formulation of empirical knowledge as aprioristic empiricism (Grant 2006, 107). From the standpoint of the 1800 System, transcendental philosophy, whether Kantian or Fichtean, is not aprioristic enough in the matter of its formulation of the noumenon. On the one hand, Kant relegated the problem of the noumenon to the autonomy of reason to regulate its use for legislating knowledge; Fichte, on the other hand, "unthings" the noumenon, as Grant $(2006,101)$ explains, by proposing to infuse into the thing-in-itself the self-activity of the I, whereby the I that posits itself as absolute nullifies the need to posit the outside world. (In contrast, what is called 'unthinged empiricism', for Schelling, must rather derive its empirical nature from the unconditioned nature of the thing itself, independent of subjective appropriations).

Thus, in the sense mentioned, the philosophy of art provides a model for emending transcendental philosophy, which already suggests a mutual implication of art and philosophy, by first establishing a formative synthesis with Naturphilosophie where this mutual implication takes place, albeit, on the side of science.

\section{Organon of Philosophy}

The Philosophy of Art (1989), containing the early presentation of the 1800 System (2001), was a product of the Würzburg Lectures, which not only manifests a critical reaffirmation of the importance of art, but is also significant, as it were, for attempting to unite "the real and ideal" in the idea of the absolute. Here Schelling $(1989,103)$ has shown how art is capable of "[expressing] the manner in which particular things inhere within the absolute," thereby presenting the concept of the absolutely identical as found in the 1800 System. Perhaps the best illustration of this 
unity is painting which reflects the union of "particular forms" and "their cooperation within the whole" (Schelling 1989, 128). Schelling $(1989,129)$ elaborates at length this aspect of unity in painting, or how the art-form itself must "destroy the particular appearance of reality" which, indeed, makes the artwork real, as follows:

The tendency of art ... is not toward sense reality, but rather always toward beauty elevated above all sensuality. The expression of absolute knowledge in things is their form. Only by means of form do they elevate themselves into the realm of light. Form is accordingly the primary element in all things whereby they are also adopted for art. Color is merely that through which the material side of things becomes form. It is merely the highest potence of form. All form, however, depends on drawing. Hence, only through drawings is painting actually art, just as only through color is painting actually painting.... Art as such, however, and painting as well... must rather destroy that particular appearance of reality.

Philosophy can accomplish this (destructive) undertaking, so to speak, but only for sense-objects that reason is capable of cognizing within the bounds of experience. Beyond its transcendental remit (where synthetic a priori knowledge is ruled out by Kant), aesthetics accomplishes this transgressive unity in the 'original and natural', whereby art establishes an important and critical proximity, in the matter of the "exuberant nature [Ueberschwenglichkeit] of what is to be known," to what Schelling $(2007,159)$ would also describe of the thing-in-itself. From the perspective of art, the opposition between aesthetic intuition and cognition, notwithstanding, is presupposed, but must also be necessarily resolved in due course by dint of art's fundamental orientation toward the natural. Works of art exhibit the potency of the absolutely identical in the sense that art becomes ideal in the destruction of the appearance of reality (for instance, in painting). If by transcendental abstraction philosophy can only produce sense-objects that restrict the application of abstraction to the bounds of the sensible, art, by contrast, engenders finite products that "[gleam] ... imperfectly through the real" (Schelling 2001, 231). These glimpses are imperfect only insofar as these products exhibit the potency of the absolutely identical, and not the absolute identical itself. In this context, Scheling $(2001,231)$ can claim that aesthetic intuition is already "transcendental intuition [that has] become objective."

Whatever art produces, nonetheless, remains incomplete in the sense that art products exhibit only the potencies of the real, in contrast to the default standpoint of transcendental abstraction that decrees that the process of intellectual production must end at some point, generally, for proper legislation of knowledge. Paradoxically, both dogmatism and criticism share this terminal orientation with respect to intellectual production. Recall here Kant's rejection (B 511/A 483; 1996, 500) of intellectual intuition, and by implication, aesthetic intuition, as the final basis of knowledge, in line with the dogmatic approach of reason to close the gap between subject and object, the self and the world. Dogmatism demands a form of complete intuition in terms of 
empirical cognition of things outside of consciousness, otherwise the manifold, whereby objects in-themselves could be directly encountered without conditions. The Kantian injunction against the illusion of direct encounter, of course, is Copernican in persuasion: we cannot cognize the "existence of appearances ... apriori" (B 221; Kant 1996, 249), but only apply the conditions set by cognition for the appearances of things, not as the in-themselves of things. In the matter of aesthetic intuition that Kant nominates to the level of the transcendental (A 22; 1996, 74-75), the final intent of critical reason, vis-à-vis the dogmatic approach, is to, "segregate from sensibility everything that belongs to sensation, so that nothing will remain but pure intuition and the mere form of appearances, which is all that sensibility can supply a priori." Here sensibility is deprived of its possible connection to the noumenon, the extra-logical nature of existence that Kant attributed to the illusion of the synthetic a priori. In short, Kant (in Reiner, 1983, 41) foreclosed the possibility of synthetic a priori by making sensibility conform to reason. For Schelling $(2007,124)$, the most dangerous outcome of this foreclosure of the in-itself (that begins with Kant's technical apriorization of sensibility) is the notorious Fichtean doctrine:

The source and first foundation of all existence is in the I or, more properly speaking, the I am. In this timeless act, through which every single rational being comes to consciousness, the entire system of external existences is posited as in one fell swoop for this individual. Thus, as Fichte expresses it in one of his later popular writings, only the human species exists, everything else is only there in the necessary ideas of the I.

Back to the Kantian system, the possibility of aesthetic intuition crossing over into synthetic a priori is either exiled into the unknowable or appropriated by the selfconstituting ego. It is in this context that Schelling $(2007,231)$ argues that, "art ... ever again continues to speak to us of what philosophy cannot depict in external form, namely the unconscious element in acting and producing, and its original identity with the conscious."

\section{THE UNITY OF THE IDEAL AND THE REAL IN AESTHETICS}

More so, as Schelling $(2001,231 ; 229)$ argued in the 1800 System, art sees to it that transcendental abstraction upon which philosophy is hinged "does not rest upon a purely subjective deception," which thereby secures, with art as its sole organ of expression, its entry into the general intellect. In the Würzburg lectures, this important point comes to light via the notion of persons in the matter of attaining balance.

In Schelling's $(1989,249)$ notion of persons, the contradiction, for instance, between freedom and necessity is resolved through the ideal-type in whose exceptional nature as person autonomy can prevail "without the course of necessity being interrupted." No more than in the person of the ideal type, which is the genius, that this 
internal and subjective contradiction, or rather, the mutual indifference of freedom and necessity, which is also an indifference that constitutes their unity, is resolved. The artist's personality serves as the document of this mutual indifference: the artist crafts herself in the most subjective and conscious manner possible, but also, at the same time, is crafted by her finite creations, objectively and unconsciously. For Schelling (2001, 219), the artist does not represent this becoming objective, her becomingunconscious on the level of concepts, but rather, in the realm of ordinary experience. For its part, philosophy takes from ordinary experience what it elevates to concepts. Nonetheless, what it takes and conceives from the ordinary must already be objective in itself as a model of self-creation. Works of art are devoid of conscious traces in the sense that they are reflective of 'things' rather than of the manifest subjectivity of their makers.

In this sense, the unconscious is absorbed into the subjectivity of the philosopher who can now proceed subjectively by objectifying the unconscious of art. Here the philosopher arrives at the most objective, devoid of conscious and subjective traces, namely, the concept. The objectivity that art makes for philosophy's sake settles the distinction between subject and object, upon which discursive knowledge is based, into the identity between the two, the same identity that, as Schelling $(2001,230)$ earlier described, has "already divided itself [...] in the self," referring to the self that transcendental philosophy claims in self-awareness. But because the identity in question is non-objective (non-objective to the self), it follows that the identity of subject and object cannot be "called up to consciousness [and be] understood" (Schelling 2001, 229). This non-objectivity is resistant to reflective consciousness (and determinate judgement as well) since it is already objective even "before reflexivity divides" (Cf. Matthews, Schelling 2007, 51). Simply put, this pre-reflective objectivity is the non-objective essence of the objective. With its reasoning limited to reflection and determinate judgments, philosophy can only ever hope to resolve this opposition. In the end, it is forced to resolve the contradiction in the schema of moral freedom as a consequence of apriorizing sensibility in the matter of the regulative use of inexponible postulates.

The identity-system, which for Schelling amounts to a general reconfiguration of philosophy as philosophy of art, challenges this form of apriorization by sustaining the restlessness of aesthetic self-making whose original derivation lies in the presynthetic. In the matter of this apriorization, Kant (Ak 313-314; 1987, 182), for instance, enlisted the genius as a vehicle for the "presentation of the imagination," an aesthetic idea, which, according to him, in a dense passage that follows, "prompts much thought, but to which no determinate thought whatsoever, i.e., no [determinate] concept, can be adequate, so that no language can express it." In short, the genius is summoned to legitimize the restraint on synthetic a priori which, for Schelling, can only refer to the inexhaustible dynamism of the pre-synthetic. For Kant, only the genius can rationalize an expression of indeterminacy, such as an 'aesthetic idea' which is flagged by the understanding to be the only conceivable presentation of imagination which, apparently, art cannot undertake as a consequence of its prereflective origin in natural drives, merely capable of attaining imagined wholes. 
Accordingly, as the following passages would reveal, Kant (A 615/ B 643; 1996, 586) himself was confronted with this gnawing question of origin:

What is the cause that makes it inevitable for us to assume something, among existing things, as in itself necessary, and yet at the same time to shrink back from the existence of such a being as from an abyss? And how do we set about bringing reason to an understanding with itself on this issue, so that it may get away from the wavering state of a timid approval, which it always takes back again, and arrive at calm insight? (A 615/B643; 1996, 586)

Kant's (A 620/B 648; 599) response to the question of absolute being, which, as he asserts, "is not capable of any concept," is already proverbial: "This necessity must be one that was to be found in my reason only as formal condition of thinking, but not as material or hypostatic condition of existence." But unlike the Kantian approach to regulation and practical constitution of the formal conditions of reason, Schelling proposed to describe reason as, "not only the freedom to suspend," for example, the natural drives that provoke the understanding to overstep the bounds of the knowable, all the more, the "drives that have grown perverse" (Schelling in Lauer 2010, 5), but also in itself, "the structural precondition of perversion and thus must be open to suspension as a whole." Whereas Kant favors regulation through the a priori reduction of sensibility, Schelling pushes for the suspension or continual overcoming of reason (Matthews, 2007, 26) which by contrast, grants the in-itself (Schelling 2007, 68) the 'unprethinkability' of the essence of the original and natural, "that before which nothing can be thought." Kant resolves that the antinomies of the understanding call for a practical approach: if reason cannot allay its own demand for the unconditioned beyond its power to attain the impossible, it ought to bring to realization instead a distinct moral world. Suffice it to say, the moral world seals the question of existence, and thus the unprethinkable, by "[depriving] speculative reason of its pretensions to transcendental insight" (B xxx; Kant 1996, 31). But as Schelling $(1989,8)$ argues, the true suspension of reason, in the face of the unknown, can only be accomplished through art, via the philosophical "construction of art" itself. That art cannot pursue its own construction, however, is a given assumption: art has no interest in concepts (as far as Schelling is concerned).

Thus, the philosophical construction of art serves two purposes: 1) to reclaim art's fundamental connection to sensibility by making the real consistently intelligible without repeating Kant's gesture of apriorizing the sensible, and 2) to underscore philosophy's rudimentary aesthetic root. Art cannot be of use to philosophy, or to any other science for that matter, without this free construction modeled accordingly on the scientific understanding of Nature. By scientific Schelling (1989, 281-82) means the free construction of art as a general philosophy of art. Art unites the terms (subject and object, subjective and objective) not by resorting to anything artificial via synthetic reason, but rather, by accommodating the original and natural that enables a unity of 
opposition in the form of finite products. To this extent, "all antitheses," as Schelling $(1989,134)$ states, "are expurgated in the individual," leveled off in favor of "balance."

Art unites the oppositions by bringing the self to the fundamental awareness of the pre-reflective in which any conceivable division is already united in the outcome of the creative act even before this opposition can be grounded in concepts. Suffice it to say, the pre-reflective replaces the intelligible character of the real (in the Kantian sense). Hence, the objectivity of art lies in making the 'self' objective to and for itself. This pertains to the self that has become objective through its finite creation, a kind of self-enactment in the sense that as soon as the 'self' enters the general intellect it loses itself to give way to the objective. As Schelling $(1989,250)$ argues, "the only means of representation for that relationship," the representation of self-objectivity in both philosophy and art and in terms of their symbiotic, but also mutually indifferent transformation, is, in general, the "human nature." Indeed, only in human nature can an act demonstrate the essence itself of the "power of freedom that, independent of necessity, raises its own head victoriously at the same time necessity triumphs" (Schelling 1989, 250).

Schelling identifies a paradoxical model for this sense of triumph in epic poetry, but not without the aesthetic self-making complication it generates in the matter of attaining internal balance. Without free construction in the sense of the co-implication of ideas and experiences in the form of sensations, affects, etc., the unconscious, which represents an objective material for 'individual' self-enactment, risks being suspended in favor of the dominance of the 'mass impulse' (Schelling 1989, 238). To a greater extent, epic poetry inspires this kind of ascendancy. For Schelling (1989, 241), however, even as he identifies the epic poem as an example of free construction whereby the 'individual' is suspended, he also underlines the fact that the epic poem celebrates the mass impulse if only to shed light on the possibilities for the "individual to become valid again through the highest degree of uniqueness." This is true in the case of the Homeric poems. The Iliad, for instance, portrays the commonness of the mass impulse only to later dissolve in the personal quest of the Odyssey whereby individual identity is regained through the "inner identity of culture," or rather, "the identity of the condition from which it emerged" (Schelling 1989, 238), least to say, in the background of maritime conflicts and civil wars among city-states. But in modern times, Schelling contends that what truly marks the epic genre as a model of free construction, beyond the glory of the Homeric poems, is Dante's Divine Comedy, albeit, misunderstood during the poet's time.

In Schelling's opinion (1989, 240), Dante's poesy is too incomprehensible and self-enclosed in the sense that "as its own world [it] requires its own theory." The Divine Comedy is a confused genre in itself: not properly epic "since the objects in its portrayal lack real sequence of events," thus cannot be "reproduced through intentional art (Schelling 1989, 240). This is an example of a construction of art that seeks individuality in form out of a confused bundle of objects which represent the unconscious materials that the author of the Divine Comedy sought to reference his artistic impulse from, at the risk of being indiscernible. But, as Schelling contends $(1989,240)$, the goal of the philosophy of art, vis-à-vis this incomprehensible poesy, 
is to "comprehend it not in its immediate temporal references, but rather in its universality and archetypal quality for all of modern poesy." In short, this indiscernible art genre is the model for the self-objectification of general philosophy, especially, when the appeal of the mass impulse is dominant and persuasive.

Comparatively, in inverse relation to philosophy's own pursuit of objectivity, transcendental philosophy takes to its signature recourse of disposing "everything metaphysical," as it were, in general knowledge, and even more in the matter of popular opinions, inasmuch as "the common masses," as Schelling asserts, are "not completely indifferent to the output of the mind, especially of philosophy" (Schelling $2007,106)$. In relation to the common masses, Schelling criticizes the whole objective of apriorizing sensibility just so to safeguard the categories from them, that is to say, from the popular use of dogmatism. Understandably, the outside world that critical reason had shielded its a prioris and categories from stands being countenanced by a new metaphysical content, the metaphysics of mass subjectivity, which, however, arises, not without an acceptable sentiment opposing, among others, the highmindedness of the academe that, as the masses could truly observe, has only 'held humanity', under the auspices of the a priori knowledge of the world, "in too great an isolation from the world" (Schelling 2007, 106). Critical reason assumes that only with the 'right metaphysics', the road to 'royal science', can a true understanding of the world begin, and this metaphysics is possible only within the unity of the world sustained by the a prioris.

However, critical reason and mass subjectivity belong to the same activity that holds the self and the world in a mutually contradictory relation such that they can be united as one in the same activity. As Schelling $(2001,230)$ once asked "What is that wonderful power ... whereby ... an infinite opposition is removed?" That which, for instance, "appears to us outside the sphere of consciousness" (which is the basis of pure reason's apriorization of sensibility) and "that which appears within it, as ideal, or as the world of art," otherwise, the aesthetic principle that states that the infinite is in the finite, the universal in the particular, etc., "are also products of one and the same activity" (Schelling 2001, 230-231)." The name of this activity is imagination or productive intuition. This is the same activity that is generally current in the mass impulse, namely, the objectivity of the world beyond the categories of reason. But, as Schelling $(1989,241)$ asserts, only art can step into conflict with the mass impulse by "extracting enduring forms from the mixture of [the] age."

It is this sense that Schelling $(2001,230)$ argues, "that which the philosopher allows to be divided in the primary act of consciousness, and which would otherwise be inaccessible to intuition, comes, through the miracle of art." On the flip side, transcendental philosophy resolves the dichotomy of subject and object by allowing the contradiction to persist between a non-existent self ${ }^{1}$ (without free construction, the self cannot become objective to itself, unable to produce itself as 'self') and transcendental freedom (in principle, a noumenal postulate in Kant). Here Schelling agrees with Fichte's critique $(2005,32)$ of Kant's system according to what it lacks by returning what it does not address to the domain of primary act: "[In Kant's Critique 
of Judgement] we find the confession that the sensible and supersensible worlds must come together in a common but wholly unknown root .... separate from the other two and self-sufficient." As Fichte adds, if the two self-sufficient worlds are to be united, what unites them must in itself be absolutely inconceivable. But as such, reason, "will conceive it just as it is, i.e., absolutely inconceivable ... and thus too it will conceive the point at which absolute conceiving is able to begin" (2005, 32). Even so, as Schelling (in Dodd 1998, 54-55) detects, Fichte tends to resolve the duality of the sensible and supersensible in terms of a "radical point of separation [Trennung]" from the unconditioned or Absolute, as it were, removed from it.

For Schelling, the Absolute is conceivable rather aesthetically. Art brings the self to a realization that, "what this odd separation expresses, is not really an actual division, but rather a distinct pathos of thinking, where thinking is plagued by the confusion over the difference between the 'being' of universality and the 'being' of separation from the universal" (Dodd 1998, 54). Schelling calls this confusion, in reference to the inherent tendency of art, a "divine chaos." As he remarks in the Würzburg Lectures, divine chaos pertains to "the inner essence of the absolute which resides as one and one as all [or] primal chaos itself” (Schelling 1989, 88). Without aesthetic cognition, philosophy will remain unaware that this absolute resides internally in reason and until it is freely constructed the understanding will never recognize its 'inner essence' as Nature. Thus, by the initial vision of chaos, an aesthetic cognition of the world begins which further leads to the understanding of Nature as 'divine chaos'. Schelling $(1989,88)$ argues:

Through this vision of chaos, the understanding passes over to the perception of the absolute, be it in art or science. After unsuccessful attempts to exhaust the chaos of the phenomena in nature and in history by means of understanding, ordinary perception or knowledge resolves to take 'incomprehensibility itself'... as a principle of judgment.' This appears to be the first step toward philosophy, or at least toward an aesthetic view of the world. Understanding can recognize the world as the true symbol of reason itself only within such an unbounded condition, one appearing to common understanding as lawlessness, or only within such independence and freedom from restrictive conditions.

In relation to epic poetry, Homer, for instance, could not imagine himself saying 'there was lightning'. Rather, under the initial order of chaos, he resolved to say, 'Zeus sent lightning bolts' (Schelling 1989, 217). Even so, it is already a glimpse of the absolute in the sense that it can evolve into the understanding as the true symbol of the world, say, 'Zeus' lightning bolt' which in itself is an image of the understanding ('lightning'). But before this image develops into a true symbol of the world as absolute, aesthetic intuition of chaos brings the understanding to the awareness of the sublime (which is different from the way Kant later conceived of this form of judgment). In hindsight, the sublime, according to Kant, must in the last instance give priority to the understanding by means of reflective judgment vis-a-vis aesthetic 
cognition. The sublime deals with purpose in nature; the aesthetics with judgment of beauty. In a complementary discussion, one can say that here the third Critique rationalizes the inexponibles of the first Critique which are purported to function beyond the categories as the most conceivable limits of transcendental deduction. The third Critique would simply paint them with a purpose, via the teleological argument whose primary object of study is nature. The inexponibles can now be raised to the 'final aim' of reason, for which, as Kant (B 7; 1996, 48) argues as early as the first Critique, it "would no sooner dare anything, even at the risk of error, than give up such treasured inquiries." This refers to the speculative interest of reason to pursue the cognizability of improbable postulates, such as God, freedom, and immortality, which are all dependent on the metaphysical idea of nature that provides all our concepts and ideas with purpose, provided that their usefulness for cognition is restricted to the sublime application of the categories. But this also suggests that through the sublimation of the inexponibles in the matter of imbuing them with purposes, which later culminates in moral intelligence (Ak 446; 1987, 335), Kant can dispense with the speculative insights of reason as regards their extra-logical nature that the first Critique struggled to explain, sans the full weight of teleology (Ak 264; 1987, 123). Thus, with the teleological argument Kant would resolve to define the sublime as "the voluntary subjection of [reason] to the pain of self-reprimand so as to gradually eradicate the cause of these defects," which simply suggests that any unprincipled use of the understanding, otherwise stated, the speculative activity of reason devoid of a teleological support (speaking of the limitations of the first Critique), leads to dogmatic errors of reasoning.

By contrast, in Schelling's philosophy of art, the intuition of the sublime in chaos takes the understanding back to its fundamental condition of possibility, namely, aesthetic intuition. In the vision of chaos, the understanding is suspended in favor of "the world as the true symbol of reason," created by ordinary knowledge which "resolves itself to take [the very principle of 'incomprehensibility'] as a principle of judgment" (Schelling 1989, 88). Consequently, what follows is the suspension of knowledge from moral-practical reason that has taken the aesthetic hostage to the categories and a prioris of the understanding. The world created by ordinary knowledge stands here as the true symbol of reason. It is the world that precedes understanding, mediated by sensible intuitions before these intuitions can be grounded in theoretical understanding (as a priori intuitions), and finally in moral reason. Schelling concludes $(1989,88)$ that true understanding can only occur as the fundamental awareness of the "symbol of the absolute itself," in which everything is free and unconstrained. True understanding is possible only under the "condition in which everything [becomes] unqualified and unconditional."

To this extent, the possibility of the absolutely identical, or the actuality that is contained in the unity of the ideal and the real, is achieved by means of the aesthetic, via the finite production of the self that belongs to the pre-history of conscious reasoning. By contrast, the self as Kant perceives (Peterson in Schelling 2004, xviixviii) remains a noumenal postulate, a transcendental possibility that, regardless of its 
empirical non-existence, makes the self, "under the standing obligation to (practically) produce it," all the same function as a self. But under this condition, as Schelling (1989, 89) argued, "the element of the real revenges itself." The real takes its revenge in the sense of, "the mind [being] irresistibly driven out of the world of the phenomena" $(1989,89)$. The ground of the absolute, which lends irresoluble contradictions for reason to rectify and figure out, such as Kant's attempt to resolve the antinomies of the mind by sealing off the unknowable, indeed, prompts more contradictions than it (reason) ever thought possible to suppress. As the concept of the transcendental unity of consciousness reveals, this sealing off begins with the apriorization of sensibility that denies the self its link to the noumenon. One should not, however, mistake this access to be the key to unlocking the in-itself. The in-itself only unsettles reason when aesthetic intuition is denied of its pre-logical nature. If Kant legislates this intuition for purposes of forewarning reason of the dangers of abstraction ("intuitions without concepts are blind" [A 51; 1996, 106]), Schelling pushes the envelope by allowing intuition to unravel its natural course toward the unconditioned, or the absolute beginning itself, namely, the unconscious.

\section{The Stages of Intuition}

In his discussions of the stages of intuition in the 1800 System, Schelling described the self as the outcome of a free act, itself a form of primary consciousness (or primary intuition), in which, as he $(2001,233)$ described, "nothing determinate can as yet be posited ... since it is only first through it that any determinacy is posited at all." The self is also both subject and object; its being subject and object at the same time, however, is non-objective to itself. This is the self of transcendental apperception; in short, a self "only for the philosopher" (Schelling 2001, 234).

In the second act of intuition, the self initially acquires objectivity in terms of self-awareness, as object for itself. The awareness occurs in sensation in the sense that sensibility takes itself as objective for itself. (This is how Hume established the standpoint of skepticism against abstraction, where sense-impressions take its place). In the second stage of consciousness, the object is determined by the subject as sensation but its awareness of the objective, the external world, does not yet constitute a conscious activity. It becomes consciousness as activity (consciousness is none other than activity) the moment it learns to intuit itself as wholly objective, wherewith its activity in sensation becomes conscious sensing.

But even with conscious sensing, the external world is not posited as it is, but rather, is merely objectified by the subject as sensation, albeit, as external to itself in subjective terms possible (the sense-impressions in Hume).This indicates that, "what has been hitherto subjective is carried over to the objective" (Schelling 2001, 234), and is thus appropriated subjectively into the objective as sensing. The subjective appropriation is thereby carried into the third stage of consciousness in which the subject becomes wholly objective but only as this objectivity appears to itself as sensing. In short, this is not yet an ideal activity. What marks out the third stage is that, according to Schelling $(2001,234)$, the self deceives itself into thinking that at this 
point "nothing [remains] behind." As Schelling follows up on this point, "in this intuition a conscious activity is already implicit, or the unconscious objective ... determined by a conscious activity, save only that the latter is not distinguished as such."

But here the unconscious activity is not necessarily external to the self; it, in fact, determines the self's conscious activity in terms of production. Despite itself, the third stage of consciousness carries the first and second into the awareness of "the intuitant activity," i.e., "an ideal activity, yet of the second order, i.e., as purposive, albeit, an unconsciously purposive one" (Schelling 2001, 234). Suffice it to say, an ideal activity must be able to transform into a consciously purposive one in which the self can finally intuit itself as, "a product [that is] purposively brought forth" (Schelling 2001, 234). From the standpoint of absolute production (which is that of Nature), the self is a product, not a producer. It does not mean that the self cannot actually produce. But its nature as producer is restricted to self-becoming, at least until the fourth stage of consciousness.

The fourth stage deals with consciousness of the self as a product, and as a product, the self is an "organization, in its whole extent" (Schelling 2001, 239) To this end, aesthetic intuition completes the process of transcendental abstraction. The organization is the outcome of a process through which art produces the self. But how can the self in the process recognize itself as a product? Schelling $(2001,235)$ argues:

If the self were to continue to be purely objective, self-intuition could go on rising to higher powers ad infinitum, but the process would merely lengthen the series of products in nature without ever giving rise to consciousness. The latter is possible only if that purely objective element in the self becomes objective to the self itself. But the ground of this cannot lie in the self itself. For the self is absolutely identical with this purely objective element. The ground can therefore lie outside a self.

For this reason, the becoming objective of the self that is produced by an external ground, and is therefore, objective in the true sense of the term, is essentially an, "[intuition of] its original identity with the objective" (Schelling 2001, 236). But true to the objectivity that denies the self its complete independence with respect to the absolute, this original identity is impossible to be intuited in freedom. Devoid of absolute intuition, freedom, however, can transfigure into "consciousness that creates itself ab initio" (Schelling 2001, 236). In the sense of self-creation, it becomes an ideal activity that produces itself as absolute contingent which exhibits the unity of infinite and finite in the finite product itself, namely, the self (as personality). Schelling (2001, 236) concludes his discussion of the stages of consciousness by stating that, "this absolute contingency in the highest power of self-intuition is what we designate by the idea of genius." In this sense, the whole process of objectivity ends with nature as conscious producer of finite products; a process that transcends the second order of ideal activity, that of 'unconscious purposive one'. In short, nature becomes 
consciously purposive in the ideal-type, the genius.

\section{FREEDOM AND NATURE: THE SCHEMA OF LIFE AND THE UNCONDITIONED}

In relation to the idea of genius, let us try to extrapolate two critical pair of correlations concerning freedom and its relation to nature, namely, as we will designate each correlation henceforth, 1) 'contingency and conscious productivity' (that Schelling identifies with aesthetic creation and production), and, 2) 'freedom and unconscious productivity' (suggestive of transcendental philosophy inaugurated by Kant).

On the one hand, 'contingency and conscious productivity' reorients the meaning of freedom from self-positing to its fundamental condition as co-present with nature, such that the idea of founding a first beginning in freedom is already superfluous (Schelling 1980, 82). As Schelling $(2001,235)$ would later argue: "Nature does not engender [freedom] ... and where it is not already there from the first, it cannot arise." This co-presence suggests that if nature is the subject that produces finite products, then by no means freedom as a finite product is separated from nature's production.

If freedom is said to be constitutive of how life can be freely organized by thinking and acting (Matthews 2011, 264), and nature that point of indifference (Peterson in Schelling 2004, xxx; Schelling 2004, 185) that forces life to sink back to a state of homogeneity (the struggle of the two, life and nature, in evolutionary terms, guarantees unrestricted production), then freedom, contingent upon nature's indifference, is always already a part of its eternal productivity, but also, its locomotive to push objects to extinction. Homogeneity is homeostasis, the "dynamical inertia" (Schelling 2004, 186) essential for life to become an object to itself, but which also conditions life to the inevitability of termination. The organism is always an object to itself, as Schelling (2006, 6) would argue, which means the same thing: nature produces finite objects that follow the principle of "exhaustion of the productivity in the product," the highest reality of which is death which at the same time sustains the products' connection to vitality. Death guarantees that products are continually produced.

By being co-present with natural productivity, freedom, meanwhile, also gives form to original identity, the pre-reflective union of subject and object that, a fortiori, "precedes the dualism of consciousness" (Nassar 2014, 227). In the Freedom essay, Schelling $(2006,53)$ describes this radical conception of freedom as follows:

Man apprehends himself in a particular form in the first creation and is born as that which he had been from eternity since through this act even the type and constitution of his corporeal formation is determined.... We too assert a predestination but in a completely different sense, namely in this: as man acts here so has he acted from eternity and already in the beginning of creation. 
On the other hand, concerning the second pair of correlation between 'freedom and unconscious purposiveness', the former reverts to a kind of productivity that tends to objectify the purely objective in subjective terms possible, positing the unconscious as objectifiable in itself. This produces an idea of freedom that is superior to nature, the unconscious subject of activity in which nature is affirmed in the free activity of consciousness. With the first correlation (contingency and conscious productivity), the intuition of the original identity of the self with the objective, as Schelling argued previously, is 'utterly impossible in freedom', but this impossibility also gives rise to consciousness as self-creation $a b$ initio, which is neither freedom "directed to something external" (the unconscious), nor "directed to the lawfulness of nature" which sanctions the categorical imperative (the lawfulness of reason ought to reflect the lawfulness of nature), but rather, as "free activity accompanied by consciousness" (Schelling (2001, 235-36).

Schelling $(2001,236)$ designates this free activity by the term 'choice' which is "superior to them both [self-positing and moral reason]." Choice is already set in motion in the primary act of consciousness, albeit, not distinguished as conscious. In the correlation between contingency and purposive productivity, the unconscious, that which is not yet distinguished as conscious in the primary act, becomes a "consciously productive nature that encloses and completes itself" (Schelling 2001, 236). The essential awareness of this fundamental constitution of nature in relation to consciousness precipitates into the idea of Nature as conscious production in which through consciousness that is 'brought forth' by an external ground the organization of nature becomes manifest as a visible product in terms of the Mind, which is the invisible image of Nature (Schelling 1995, 41-42). In the personality of the genius, this organization is artistically produced in terms of the 'intuition of original identity' as the productive ground of nature.

Overall, this indicates the loss of the self as practical-moral identity. Elsewhere, Schelling likens the creation of this unique and singular identity with tragic wisdom. In this context, Schelling illustrates how the condition of possibility of freedom issues from the very limits of the concept of organization. Again, 'organization' is the aesthetic production of the self whose freedom is made possible by suspending the categories and a prioris of the understanding which amounts to the cancelation of the identity that the 'self' had once acquired in the moral world, its moral freedom. Presumably, as the self enters into a mode of self-creation ab initio, it loses the moral world. This is the same fate of the tragic hero. As Schelling formulates in an earlier essay $(1980,193)$, the tragic irony of aesthetic production, or the constitution of the self as organization, in Greek tragedy, for instance, did not permit the hero/self to escape from fate, rather "had to let him succumb [...] atone even for the crime committed by fate." In this essay, "Philosophical Letters on Dogmatism and Criticism," Schelling (1980, 193) describes this loss of moral freedom as follows: "Only a being deprived of freedom could succumb to fate. It was a sublime thought, to suffer punishment willingly even for an inevitable crime, and so to prove one's 
freedom by the very loss of this freedom, and to go down with a declaration of free will." Here we can extend the analogy of tragic fate to the artistic principle of freedom, corollary to self-creation ab initio, especially in regard to the critical transition of the notion of tragedy from the Homeric poems to Dante's poesy: the tragic hero in fact escapes his given fate, a rationalized moral fate, so to speak, and thus, deprives itself of moral freedom, in order to succumb willingly to the pre-synthetic world of aesthesis as the experience of incomprehensibility itself (which is the highpoint of Dante's genre), i.e., the world without the notion of the 'given' and the presupposition of a 'determinate being'.

Even so, if the moral world is said to be concerned with possibilities, its forfeiture may threaten the moral world with absolute objecthood (devoid of possibilities, any given world cannot allow freedom). But, as Schelling (1980, 195) also asserts, what threatens, "moral existence [...] with extinction," is the mere assumption, on practical grounds, of the existence of the moral self. The existence of the moral self in practical-moral reason presupposes that absolute, albeit, unattainable knowledge is conditioning a limited form of freedom which in turn presupposes a moral subject. But the irony gets even more complicated. The moral subject has the capability to limit the knowledge of the world, which also speaks of its potentially limitless objectifying power, such as the power to objectify knowledge that it can deem absolute. With Kant and Fichte as his targets, Schelling $(1980,195)$ argues: "Has it ever occurred to [them], ever so dimly, that [...] it is not the limitation of [their] knowledge, but [their] unlimited freedom which has relegated the objects of cognition to the confines of mere appearances?" To the extent that absolute freedom 'relegates objects to the confines of appearances', to that extent freedom imitates the pure objectivity of nature, indifferent to all appearances and objects, which according to nature's highest indifferent power is tantamount to the imitation of death. Ironically, this objectification is only restricted to the ideal, effectively leaving the real foreclosed to scrutiny. But the real, where nature belongs, contains its own objectivity, which is pure objectivity in the sense of its leveling power of extinction. Schelling $(2017,30)$ describes this power, vis-a-vis the aspiration of transcendental philosophy to attain infinite continuance on the level of the ideal, both in its Kantian and Fichtean connotations, in terms of its power to force "the world known to us" to collapse "with the world of nature." Schelling $(2017,30)$ concludes this point in his later work on Naturphilosophie as follows:

Only at that point where the ideal has become real, the world of thought [has become] the world of nature, only at this point lies the last, the highest satisfaction and reconciliation of knowledge, as the fulfillment of the ethical requirements is reached only when they no longer appear to us as thoughts, for example, as commandments, but rather have become realities in the nature of our soul.

Thus, in suspending the moral world, the intuitant is rescued from a needless form of extinction, a form of immoral extinction, to say the least, which, accordingly, 
refers to a kind of extinction that does not deliver. As Schelling $(1980,157)$ earlier elaborated, the notion of the collapse of the known world challenges the notion of a world immortalized by practical reason (via a reverse collapse of the natural world in the expressed formulation of the moral foreclosure of the in-itself of metaphysics). In truth, this reverse collapse suppresses possibilities in the sense that the intuition of the unity of antitheses in practical reason is lost as a result of the cancelation of the 'other' of reason, the exuberance of the pre-synthetic, when neither the conflict nor the unification of ideal and real, conscious and unconscious, subject and object, etc. "is any longer possible in us." The immortality of the moral soul corresponds to an infinite failure to guarantee that a sacrifice of the external world will bring about its desired outcome, the kingdom of ends, which possibility merely rests on a forceful caricature of an open-ended future, as if the not-yet and the to-come can be isolated from natural productivity whose unrestricted production forecloses the very notion of mere possibility in favor of constant self-recapitulation of eternal production. As it appears, this is a criticism of Kant's concept of immortality, a finite striving to become infinite based on a metaphysics of morals that depends on a concept of personality as the world's guardian (based on a different concept of genius, as we elaborated). Schelling $(1980,99)$ argues:

The ultimate goal of the finite $I$ is therefore an expansion toward identity with the nonfinite. In the finite I there is unity of consciousness, that is, personality. The nonfinite I, however, knows no object at all and therefore no consciousness and no unity of consciousness, no personality. Consequently, the ultimate goal of all striving can also be represented as an expansion of personality to infinity, that is, as its own destruction. The last goal of the finite I as well as that of the not-I, that is, the last goal of the world is its destruction as a world, that is, as an embodiment of finiteness (of the finite I and the not-I). In order to approach this ultimate goal, an infinite approximation takes place, therefore an infinite continuance of the I, immortality.

Thus, for Schelling, the most active life of freedom lies in the destruction of the world known to us, that is to say, its destruction in the ideal. In short, the ideal is the battleground of the correct intuition of the real. With the destruction of the ideal in the ideal, the real is intuited, thereby finally destroying the ideal itself. Suffice it to say, this is the task of the ideal-type, destroyer of the moral world.

\section{CONCLUSION}

As Schelling $(1980,157)$ contends, there is only the future as a promise when something is "put between [the world] and [the self]" with which to restrain the intuition of the real world in which this restraint translates into a false collapse - as we described, an immoral extinction. Without the intuition of the real world, the 
"unification of two opposing principles," the real form of collapse, is foreclosed, hence, the corollary collapse of real beauty, the "reciprocal yielding in contest [between the world and the self] $(1980,157)$. With beauty, the moral world is suspended in favor of aesthetic intuition. In the moral world, the future is located within a space of difference that sets the world and self apart, from which it derives its promise of possibilities. It is in this context that the pursuit of beauty is the pursuit of truth, the unity in duality: "For truth, just as beauty, is ideally the identity of the subjective and objective. For truth, however, this identity is intuited subjectively or prototypically, whereas for beauty it is intuited objectively ..." (Schelling 1989, 31). The unity in duality (truth in beauty) threatens the moral world that bases itself on the infinite difference between world and self with a difference-leveling extinction. True beauty is destructive of the world. True beauty is the aesthetics of extinction.

But first, Schelling had to rescue aesthetics from the idea of the divine which is the result of the stipulations of practical reason that demands the unconditioned. In his earlier essay "On the Nature of Philosophy as Science," Schelling (Marcus in Bubner, 1997, 217-18) argues that for a true philosophy to find a starting point, it "[has] to depart even from God." He (218) adds, "those who look for true philosophy must be bereft of all hope, all desire, all longing." Already this is a statement critical of the redemptive promise of possibilities that transcendental philosophy offers to systematization and regulation by the categories and a prioris of reason; hence, a lifeless world governed by simply the ideal. But, it is not only for conspiring against the world that Schelling's $(1980,185)$ idea of philosophy first targets the idea of the divine, but also, most importantly, to "awaken [the intellect] as from a state of death." In our appropriation of this concept of death, the world of moral reason envisioned by transcendental philosophy is, in fact, a lifeless version of the same life from which it self-activates; oddly put, a kind of death that refuses to accept it is already extinct, that is, as an ideal, devoid of an ontological support in the real, and therefore, is dead in the real, which altogether forfeits its actuality. This actuality consists of the unification of two opposing principles, between self and the world, the ideal and the real in the truth of beauty. Without beauty, all possibilities in the ideal will forever be empty.

But also, as Schelling $(1980,185)$ would argue here and there, the awakening as from death is also the, "awakening as from intellectual intuition." Recall here that both Kant and Fichte stopped dead at intellectual intuition: on the one hand, Kant restricted its use to the apprehension of the practical structure of external reality; on the other hand, Fichte conceived of intuition as that which the I can appropriate, enacting a "transition to not-being" that the Ego can objectify in the sense of an instrument. In both instances, the fate of intuition becomes a complicated task for thought to unravel:

Intuition [Anschauung] as such is usually explained as the most immediate existence; correctly so, as far as it goes. Yet, the more immediate experience, the closer to disappearance. Even sensuous intuition, as long as it is only what it is, borders on nothingness. Should I maintain it as intuition I would cease to be I: I must grasp myself with might in order to save myself from the abyss of intuition .... The I, on 


\begin{abstract}
finding resistance, is obliged to take a stand against it, that is, to return into self. However, where sensuous intuition ceases ... there is nothing but infinite expansion without a return into self. Should I maintain intellectual intuition I would cease to live: I would go 'from time to eternity.'
\end{abstract}

Thus, one must stir oneself out of the inertia of intellectual intuition that transcendental philosophy, as it were, has overwhelmed with apriori deductions just so to produce a notion of the world in two senses: lifeless and dying. (Hegel [1977, 83] would later echo this point in the Differenz essay, citing Schelling's Naturphilosophie's strength in terms of responding to "the need for a philosophy that will recompense nature for the mishandling that it suffered in Kant and Fichte's system."). The first sense naturalizes moral reason; the second celebrates infinite expansion in the form of the self's 'supreme positivity' unable to return to itself: "unlimited activity is absolute repose - perfect Epicureanism" (1980, 185). For Schelling, to awaken from intellectual intuition as from a state of death means to induct conscious activity with the aesthetic approach to productive intuition. Accordingly, aesthetic intuition redirects intellectual intuition to an, "activity intent upon objects," (Schelling 1980, 185) which transcendental intuition otherwise delivers to the jurisdiction of the a prioris and categories in which objects become devoid of activity independent of the stipulations of cognition. This renewed engagement with objects allows the self to 'return to itself' (from the standpoint of nature, the self is an object in the first place; in short, the self has no objectivity of its own). The return of the self in conscious activity on the grounds of aesthetic intuition presumably frees the self from the moral world in order to become a self that is neither animal nor dead, but rather a self in the process of self-creation $a b$ initio. Schelling $(1980,185)$ summarizes this whole point below:

We awaken from intellectual intuition as from a state of death. We awaken through reflection, that is, through a forced return to ourselves. But no return is thinkable without resistance, no reflection without an object. We designate as alive an activity intent upon objects alone and as dead an activity losing itself in itself. Man ought to be neither lifeless nor merely alive. His activity is necessarily intent upon objects, but with equal necessity it returns into itself. The latter distinguishes him from the merely living (animal) being, the former from the lifeless.

In this renewed encounter, objects are celebrated as they are in-themselves, which, in consequence of their interaction with the self, deliver the self to a fundamental understanding of the exuberance of existence; a self-realization that outside of cognition, objects are neither objects nor subjects, thereby revealing a common root, which is their identity in the unprethinkable, defined as the "equal validity" between subject and object, as "indifference of the subjective and objective" 
(Schelling 1994, 162). With the non-objectivity of the object in itself, and also, with the subject that has no objectivity of its own, the self becomes aware of its relation to itself and to objects outside of itself as an activity of the subject strictly not itself. (In short, a subject without an object is not a subject). For that reason, this non-objective self belongs to the purely objective in the sense Schelling defined it as not-self (unconscious). It is in this sense that the 'self' returns to itself, ab initio, but only when the normative gap between subject and object, self and the world collapses in favor of existence in which the actuality of the unprethinkable is lived through, and where the gap between world and self is abolished. This 'self' undergoes transition as does Dante's Divine Comedy, which is too important for Schelling to elevate to the exemplary: from the self's chaotic vision of the world, to its tragic awareness of the unprethinkability that sustains this contradiction, and finally, to the organization of the self as personality that nourishes this conflict in the form of refashioning itself with objects, the materials of the unconscious, from which it gathers a unique self, needless to say, in the same manner as Dante's oeuvre becomes of itself an incomparable genre/self.

This self is none other than the self of the true immoralist, transgressor of the normative balance between conscious and unconscious, subject and object, the self and the world; hence, in terms of personality, the destroyer of known worlds, the genius.

\section{NOTES}

1. We are here referring to the empirical I, which as Schelling contends, and as Peterson echoes in his annotation of First Outline (Peterson in Schelling 2004, xviixviii), "could never theoretically affirm the sheer absolute reality of the I but is under the standing obligation to (practically) produce it."

\section{REFERENCES}

Bubner, Rüdiger. 1997. Fichte: Introduction. In German idealist philosophy. Edited by Rüdiger Bubner. England: Penguin Books.

Dodd, James. 1998. Philosophy of art in Schelling's 'System des transzendentalen idealismus'. The Review of Metaphysics 52 (1).

Fichte, Johann Gottlieb. 2005. The science of knowing. Translated by Walter E. Wright. New York: State University of New York.

Grant, Iain Hamilton. 2006. Philosophies of nature after Schelling. New York and London: Continuum.

Hegel, G.W.F. 1977. The Difference between Fichte's and Schelling's system of philosophy. Translated by H.S. Harris and Walter Cerf. New York: State University of New York Press, Albany.

Kant, Immanuel. 1987. Critique of judgement. Translated by Werner Pluhar. Indianapolis/ Cambridge: Hackett Publishing Company. 
. 1996. Critique of pure reason. Translated by Werner S. Pluhar. Indianapolis/ Cambridge: Hackett Publishing Company, Inc.

Matthews, Bruce. Introduction. F.W.J. Schelling, The grounding of positive philosophy: The Berlin lectures. Translated by Bruce Matthews. New York: State University of New York Press, Albany.

Nassar, Dalia. 2014. The romantic absolute: Being and knowing in early German romantic philosophy, 1795-1804. Chicago and London: The University of Chicago Press.

Schelling. F.W.J. 1980. Philosophical letters on dogmatism and criticism. In The unconditional in human knowledge: Four early essays. Translated by Fritz Marti. Cranbury: New Jersey.

. 1989. The Philosophy of art. Translated by Douglas W. Scott. Minneapolis: University of Minnesota Press.

1994. On the history of modern philosophy. Translated by Andrew Bowie. Cambridge: Cambridge University Press.

1997. On the nature of philosophy as science. Translated by Marcus Weigelt. In German idealist philosophy. Edited by Rüdiger Bubner. London and New York: Penguin Books.

. 1995. Ideas for a philosophy of nature. Translated by Errol Harris and Peter Heath. Cambridge: Cambridge University Press.

. 2001. System of transcendental idealism (1800). Translated by Peter Heath.

Charlottesville: University Press of Virginia.

.2004. First outline of a system of the philosophy of nature. Translated by Keith

R. Peterson. New York: State University of New York Press, Albany.

2006. Philosophical investigations into the essence of human freedom.

Translated by Jeff Love and Johannes Schmidt. New York: State University of

New York Press, Albany.

. 2007. The grounding of positive philosophy: The Berlin lectures. Translated

by Bruce Matthews. New York: State University of New York Press, Albany.

. 2018. Statement on the true relationship of the philosophy of nature to the revised Fichtean doctrine: An elucidation of the former (1806). Translated by Dale E. Snow. New York: State University of New York Press, Albany.

Weigelt, Marcus. 1997. Introduction to On the nature of philosophy as a science. In German idealist philosophy. Edited by Bubner, Rüdiger England: Penguin Books, 1997.

Submitted: 4 June 2018; revised: 30 November 2018. 